\title{
Management of Process and Infrastructure in Higher Education Institution
}

\author{
Ekaterine Gulua \\ $\mathrm{PhD}$ in Economics, Manager of Human Potential \\ Management Laboratory, Assistant-Professor of TSU
}

\section{Abstract}

The work is dedicated to analyzing the management challenges of higher education institutions, which are discussed from two different angles: the management process and its supporting - ergonomic and infrastructural issues. The work is accomplished under the auspices of the Human Potential Management Laboratory at Ivane Javakhishvili Tbilisi State University. The present work is a continuation of the previous research items, which were devoted to studying the perceptions of university challenges. The work is based on the qualitative analysis of the Georgian higher education system and Ivane Javakhishvili Tbilisi State University management mechanisms, also the research analysis on the attitude towards the current challenges of TSU Economics and Business Faculty students and the academic personnel. 62\% of the total composition of the academic personnel participated in the surve. The questionnaire included 48 closed and two open questions. The data was developed in the program "SPSS-Statistics". Preliminary hypotheses have been verified by statistical methods. Person correlation test, the Chi-square tests and linear regression, namely the ANOVA test are used to analyse the results. The analysis of the challenges based on the qualitative and quantitative research became the basis of searching ways to improve the management strategy of higher educational institutions. The challenges identified in the work and the suggested recommendations will help the stakeholders interested in the issue/field.

Keywords: higher education institution, management system challenges, ergonomics, infrastructure

\section{Introduction}

Improvement of the management process is ensured: by following the general fundamental principles of the management and taking the contextual features of the management object into account during the decision-making process. While implementing the management of higher education institutions, the following 
circumstance should be taken into consideration: if the university teaches along with doing scientific activities it is in the best position, since this implies that it has more opportunities for encouraging scientific work and, therefore, has a better quality academic staff.

The management status of the higher education institution is shown in the following main aspects: staff selection and personnel reserve management system; Personnel development and career management; Personnel assessment and motivation mechanisms; Control mechanisms; Level of ensuring, planning and organization of a process; The management condition of these directions reveals two fundamental conditions for the success of the higher education institution: the quality of fairness and democracy, without which ethical principles, academic freedom, impartiality and adequate quality cannot be maintained.

Fairness is the basis for a proper motivation, career development and ultimately for attracting and retaining the best personnel; While the high level of democracy in the conditions of high-qualified personnel (which is a higher education feature) is the basis for academic freedom, high quality decision making and maintaining justice.

The work is based on analysis of scientific researches, books and reports about higher education management (Antia, Vakhtang;, 2018), (Al-Hawaj, Abdulla Y. ; Elali, Wajeeh;, 2008); (Hussey, Trevor ; Smith , Patrick ;, 2010); (Babo, Rosalina; Azevedo, Ana;, 2012); (Kasradze, Tea, 2018) (Meek, Goedegebuure, Santiago, \& Carvalho, 2010); the qualitative analysis of the Georgian higher education system and Ivane Javakhishvili Tbilisi State University management mechanisms, also the research analysis on the attitude towards the current challenges of TSU Economics and Business Faculty students (Gulua, Ekaterine, 2017) and the academic personnel (Gulua, Ekaterine;, 2018) 72 academic personnel - 62\% of the total composition and 180 randomly selected, mainly the students of the fifth - eighth term participated in the survey.

The challenges of higher education institution management system: The main purpose of higher education institution depends on the level of knowledge of the academic personnel and the proper coordination of its work. The quality of higher education is directly created by academic personnel. The correct selection of the latter results in the implementation of other processes and functions at the appropriate level.

Academic personnel are selected in the higher education institution of Georgia by a competition. However, unified standards for selection criteria according to specialties are not developed, which would enable the quality of higher education management at a macro level. Quality process management in higher educational institutions is carried out by accreditation and authorization mechanisms, but it cannot provide regulation of the content of the process, in particular, the correctly developed programs and the syllabus issues also to be properly delivered to a student. 
The survey of the academic personnel has shown that the current system of personnel selection is acceptable for $58 \%$ of the respondents while $36 \%$ of the respondents gave negative answers to this question (See Diagram1(16)).

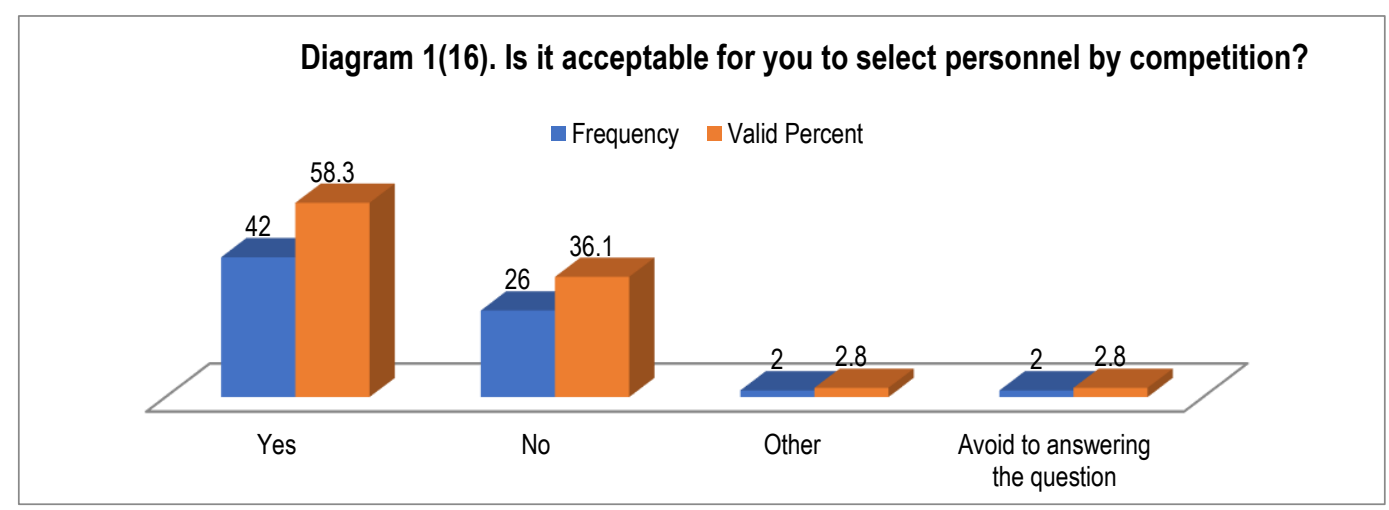

The terms and criteria of selection and the decisions connected with it taken by the academic personnel are considered transparent by $22 \%$ and $46 \%$ have a negative answer to this question; $31 \%$ consider that the development of uniform selection parameters is impossible(See Diagram 2(17).

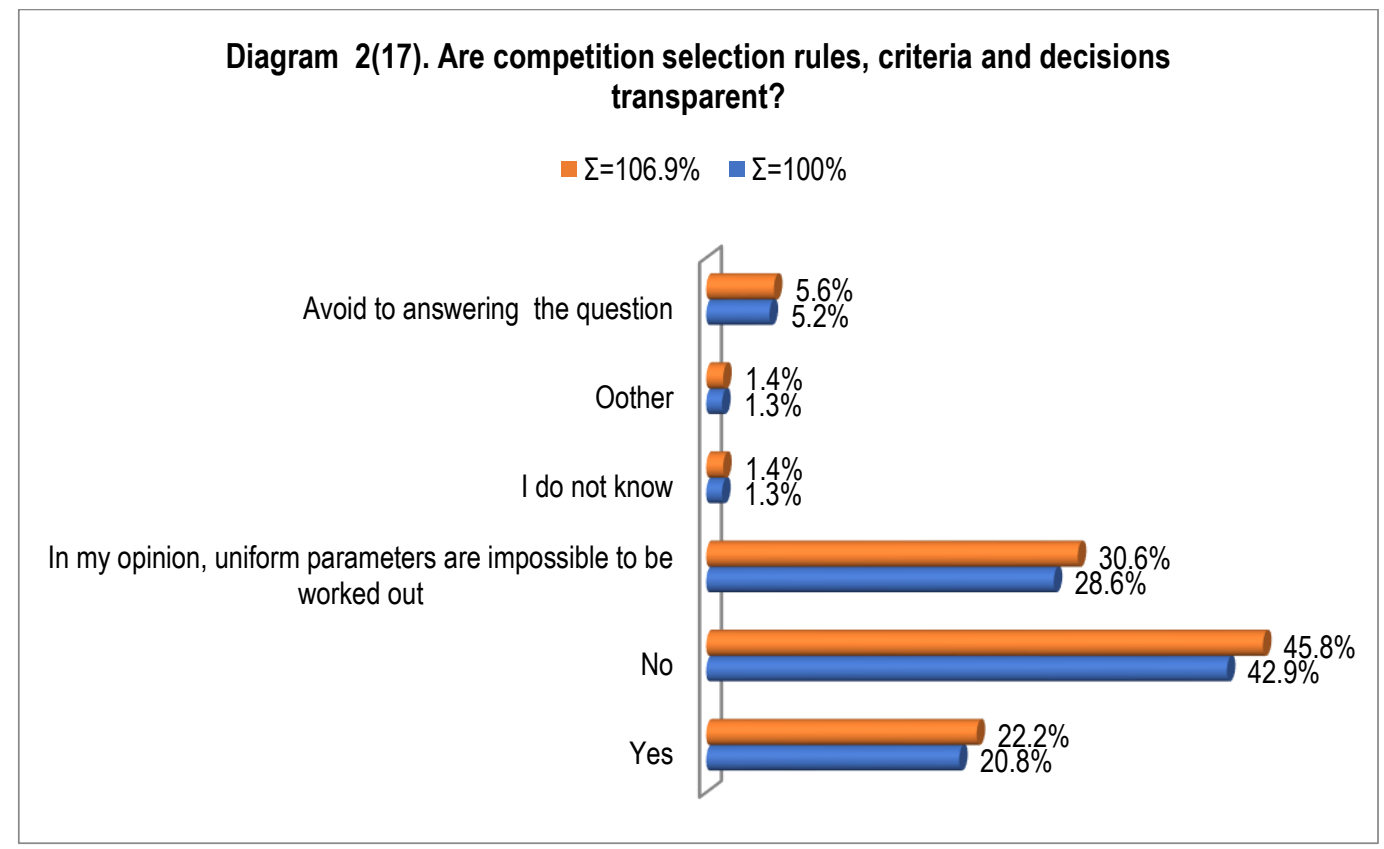

In other research, in which we studied the qualities and reasons of conflicts at TSU Economics and Business Faculty, we got interested in how transparent and objective were the criteria for selection the personnel according to the interviewed academic staff the number of which was 76. 29\% gave the answer - "always", and 57\% - the 
answer - "often" (Placeholder2). 83\% of the interviewed respondents believe that selection of personnel by competition promotes the growth of professionalism and improvement of teaching quality (in total 83\%); 36\% considers that the contest causes conflicts, $3 \%$ thinks that selection of personnel by competition is encouraging team work (See Diagram3(18).

\section{Diagram 3(18). Selection of personnel by competition improves:}

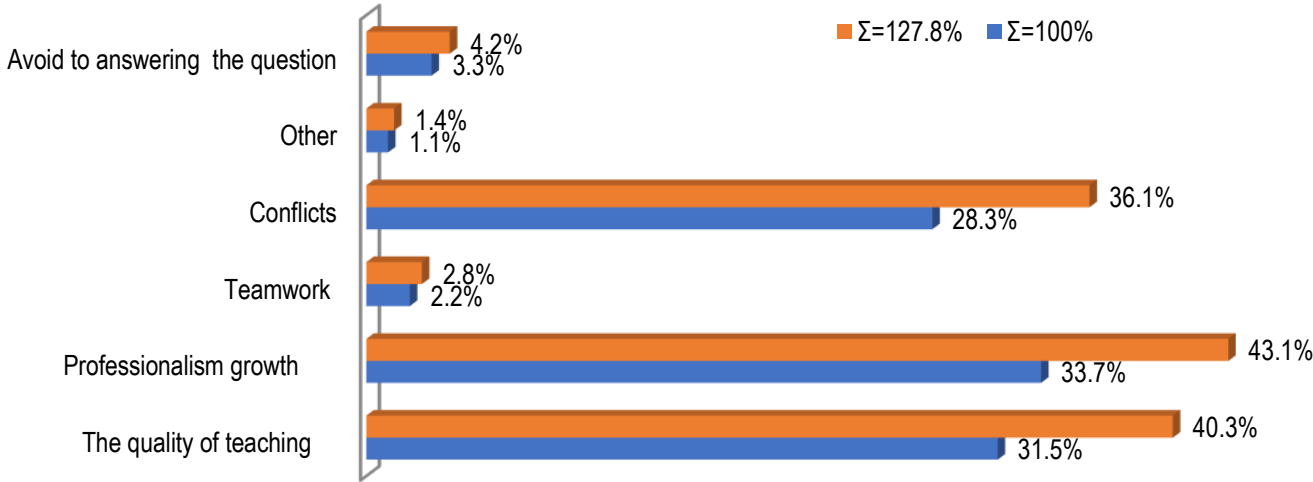

The answer to this question has been verified by another question, $61 \%$ of the respondents named the selection of staff by competition as the main reason for conflicts in the organization which is contrary to the outcome of the previous question. $44 \%$ - fight for power; $12.5 \%$ of the respondents think that conflicts take place in the organization for healthy purposes, namely, due to scientific and business disputes (See Diagram 4(20).

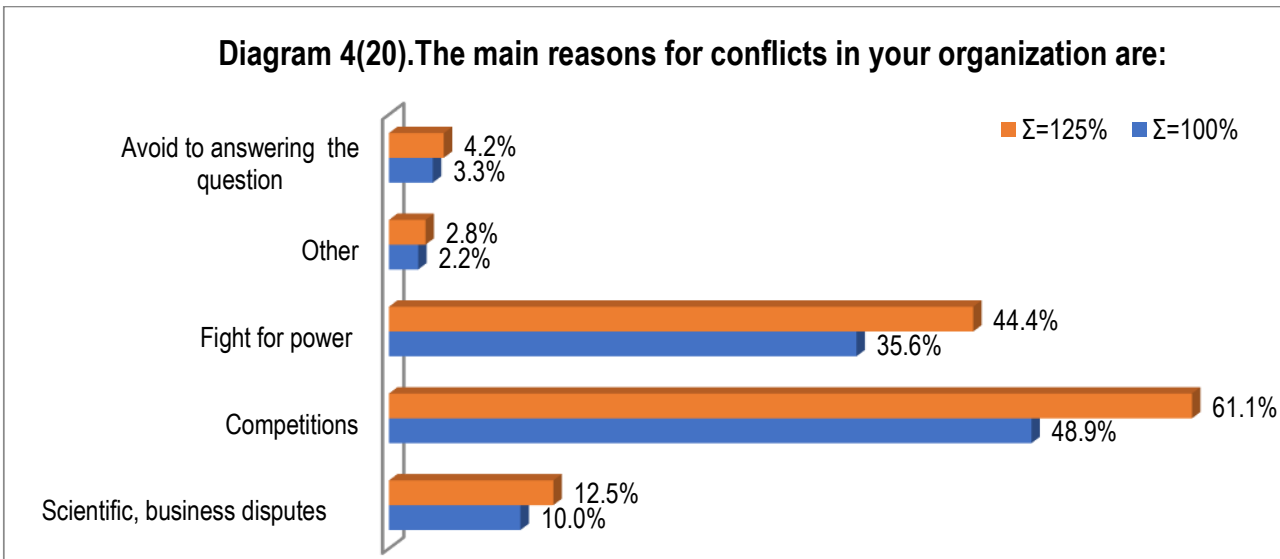

During the selection of academic staff at a higher education institution the important condition is the quality of a person's scientific work. In this regard, it is important how 
much the copyright is protected in general. Authorship of the original scientific papers significantly determines the scientist's authority. About $25 \%$ of the interviewed staff have not heard about copyright infringement, $8 \%$ believe that such a fact has not been observed; $46 \%$ reported that copyright infringement cases are rare, $18 \%$ believe that similar facts are frequent (See Diagram 5(23).

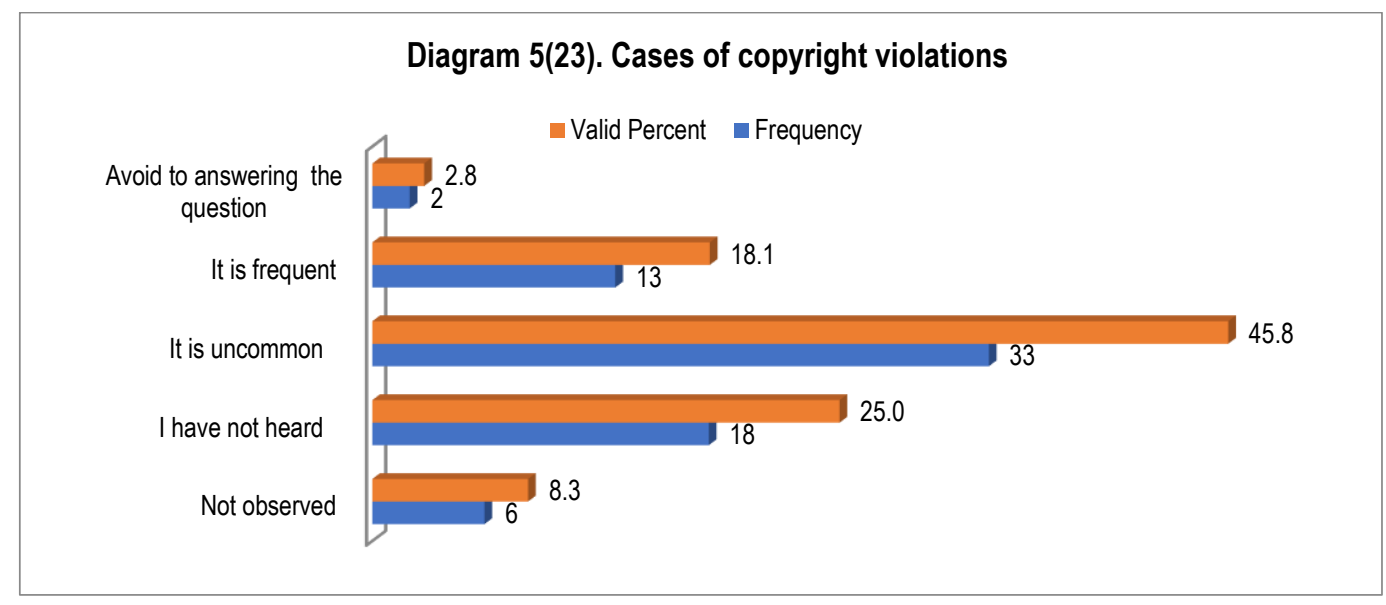

It is the best model for career management in any organization when each employee is aware of his/her career path and, moreover, he/she has taken part in the planning process of position and professional development.

The study found that for 39\% personal career advancement criteria and time frames are clear (it is noteworthy that there was no official reason for such a response in the specific situation. The study was conducted before submitting the "Professors' Assessment Criteria Project"), 22\% believes that these conditions are unclear for everyone, $15.3 \%$ thinks it is obvious for exceptions, $18 \%$ indicates that they are not only informed about career advancement, but it is even unclear whether they will keep the current position (See diagram 6(13).

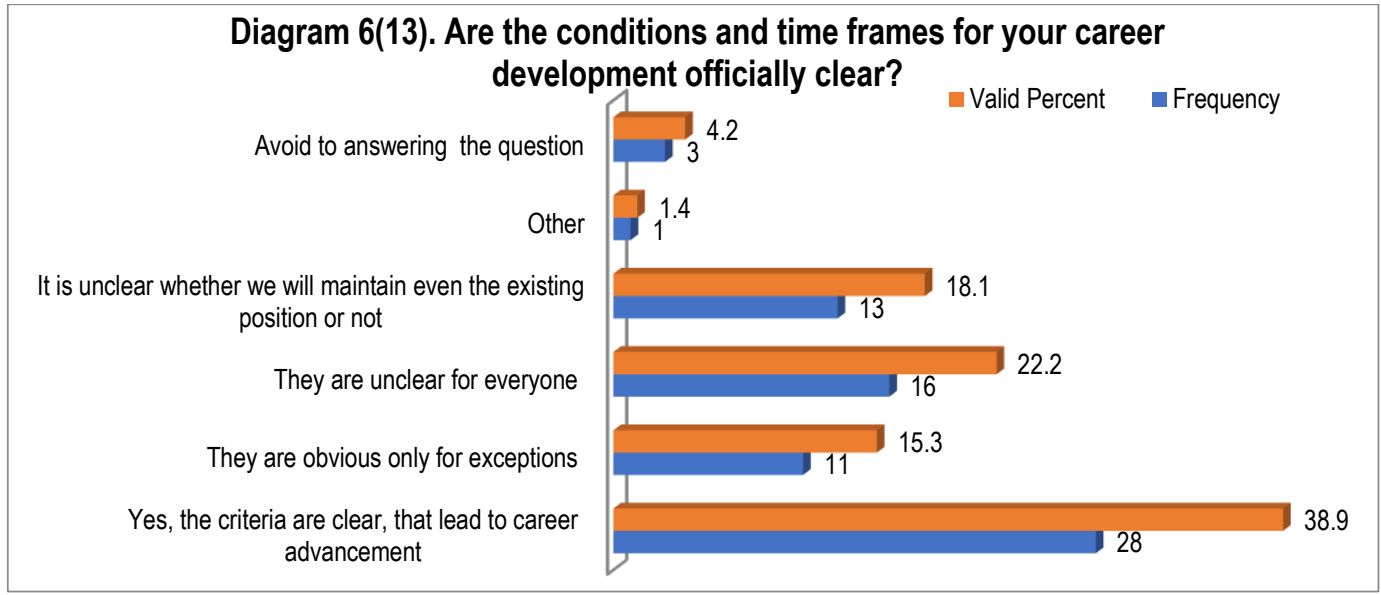


With the best modern experience a person is not promoted if he/she does not have a trained person who will replace him/her and do the job well too. The promoted person is responsible for his/her successor's future activity. This condition is especially relevant when the main resource of the organization is knowledge and its heredity (Gulua, Ekaterine; 2017); (Gulua, Ekaterine; Kharadze, Natalia; 2018); (Kharadze, Natalia; Gulua, Ekaterine;, 2018). This concept is a key value for higher education and scientific institutions. $71 \%$ do not know who will change them, $14 \%$ know and 10\% - only suspect (See Diagram 7(14).

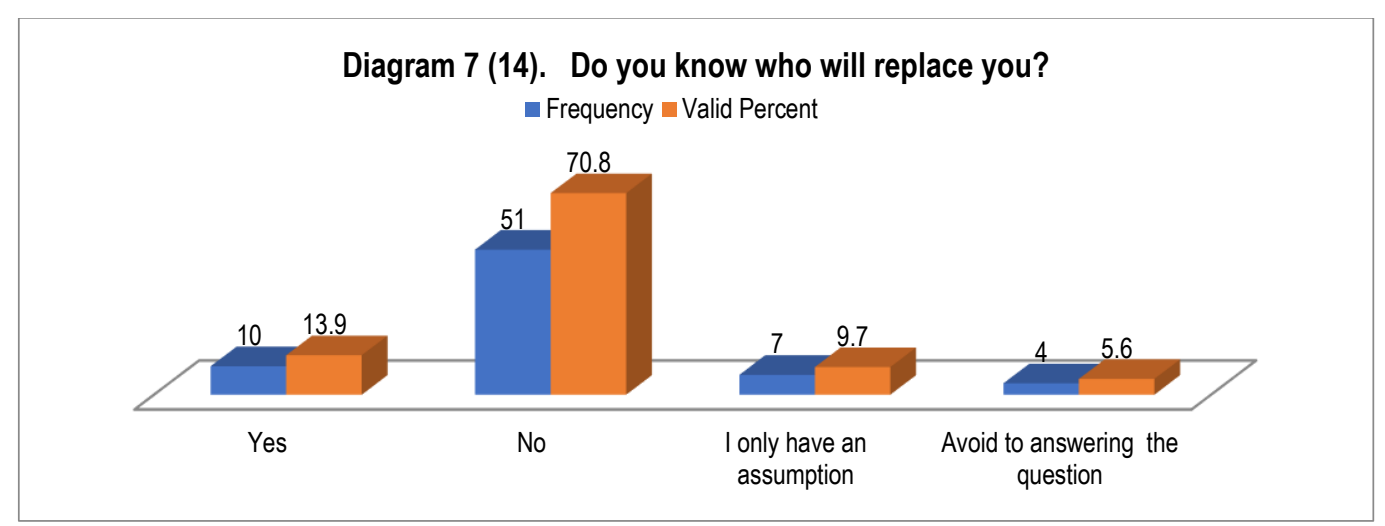

Involvement of students' decision in lecturer evaluation process is one of the approved methods of lecturers evaluation. Qualitative analysis shows that the existing practice cannot have the power of the working mechanism, because the lecturer does not have the right to a free application on the subject according to regulated schedules from the administration; In the database the students are restricted to choose lecturers, as the bases are open step by step. Students' choice would give us a real rating of lecturers if a lecturer had a right of a free application in his/her profile subjects and also the bases would be opened for all lecturers simultaneously.

$57 \%(43 \%)$ of the interviewed academic personnel believe that the lecturer's knowledge and authority influence the choice of lecturers by students; $36 \%$ (27\%) loyal attitude towards a student; $25 \%(19 \%)$ think that the student's choice is determined by electronic databases managed by a special program, $8,3 \%(6,3 \%)$ of the lecturers consider that students choose lecturers unconsciously, 4,2\% (3,2\% ) refrained from answering (See Diagram 8(15). 


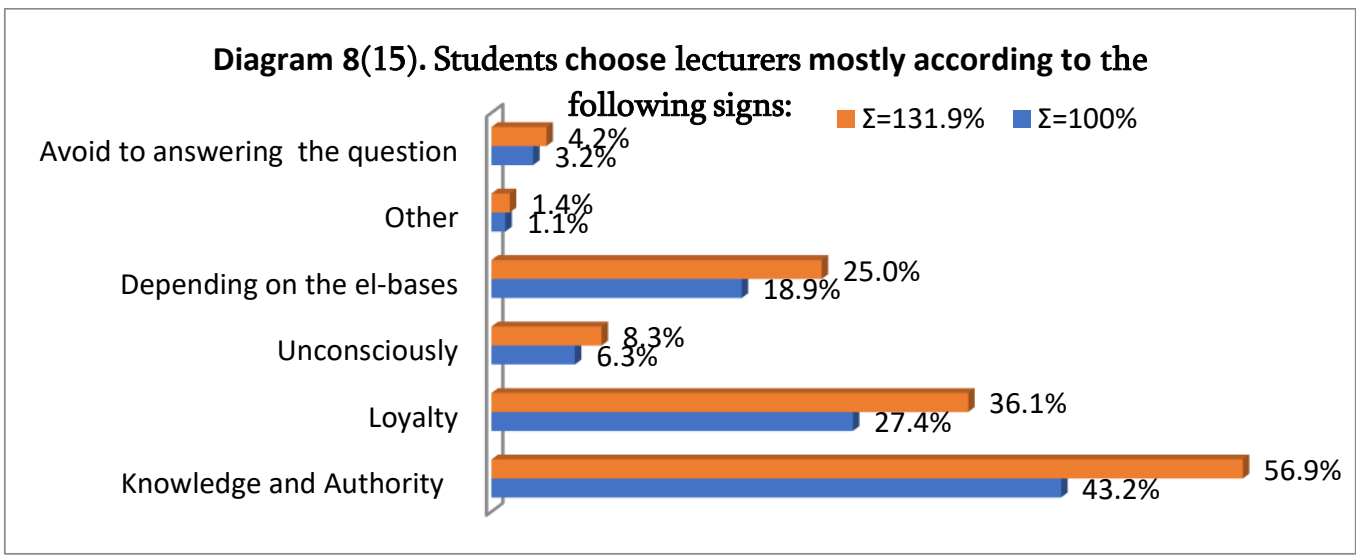

It is interesting to compare this data with students' attitude. The research on students found that $37 \%$ choose lecturers according to professionalism and competence, $35 \%$ - according to loyal attitude towards students, $27 \%$ believe that the bases restrict their freedom of choice, $2 \%$ say that they cannot make a choice. ${ }^{1}$ The analysis of students' attitude towards professors assessment criteria showed that the vast majority of students prefer the quality of the conducted lecture among the lecturers' assessment criteria and, if possible, will make his/her choice with this criterion (Kharadze, Natalia; Gulua, Ekaterine;, 2018).

The main indicator of the proper management process in the organization is the culture of established relationships between colleagues. $62.5 \%$ of the interviewed academic staff think that relations in the organization are calm and positive, $28 \%$ expressed negative opinions to this question (See Diagram 9(26).

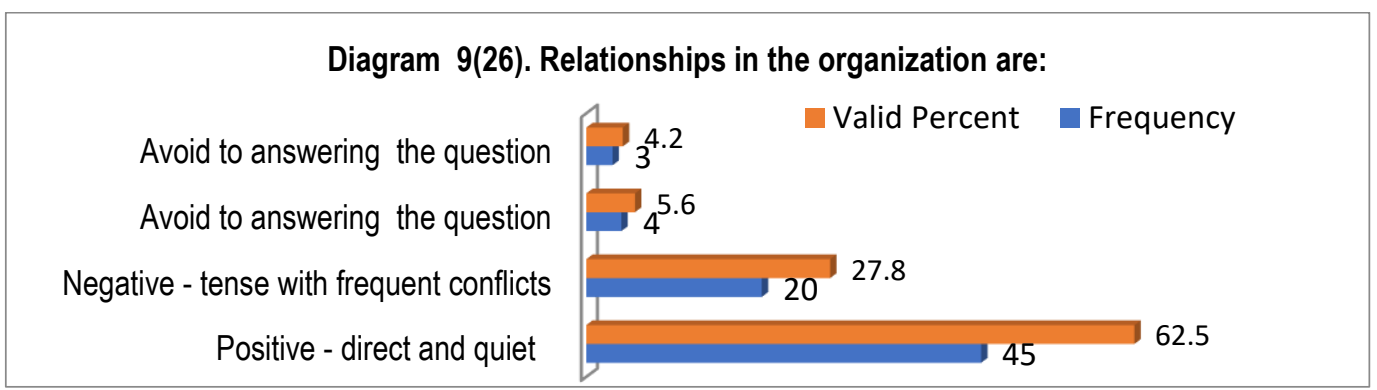

$27 \%$ of the students have never noticed lecturers' disloyal and unfriendly attitudes towards their colleagues 2 , while $78 \%$ of the students think that loyal and friendly relations are obvious $(15,6 \%)$ and frequent $(62,2 \%) .^{3}$ The intensity of informal

\footnotetext{
1 Gulua Ekaterine. Modern Challenges of Higher Education. Economics and Business, Refereed and Reviewed International Scientific and Practical Journal of the Faculty of Economics and Business, Ivane Javakhishvili Tbilisi State University, (2017 April-June Volume X, N2). Diagram 11, pg. 120.

2 The Same; Diagram N16, pg. 124.

3 The same; Diagram N15;pg.123.
} 
relations also shows the level of relationship in the organization. The research of organizational culture of TSU Economics and Business Faculty revealed that 53\% of the interviewed academic personnel (76 persons) sometimes participate in informal relationships $13 \%$ - never, $12 \%$ and $22 \%$ of the respondents indicated the answers "always" and "frequently" (Kharadze, Natalia; Gulua, Ekaterine;, 2018).

The management system has been positively assessed by $6 \%$ of the academic staff, $13 \%$ had an extremely negative position, and the majority considers it satisfactory. (See Diagram10(31).

Diagram 10(31). Organization management system is:

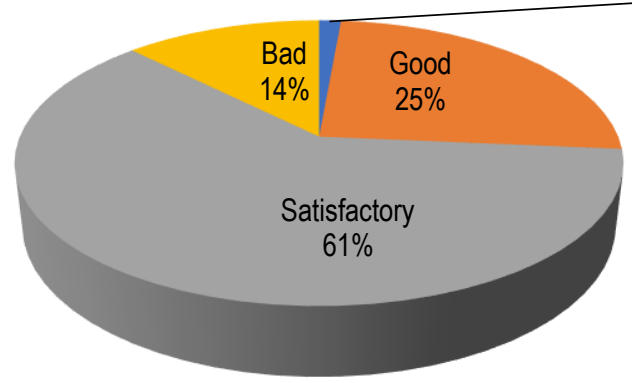

The abovementioned question was verified by the following question - $43 \%$ of the respondents believe that bureaucratic barriers prevail in the management, 36\% assess the system as democratic and 17\% - as chaotic (See Diagram11(30).

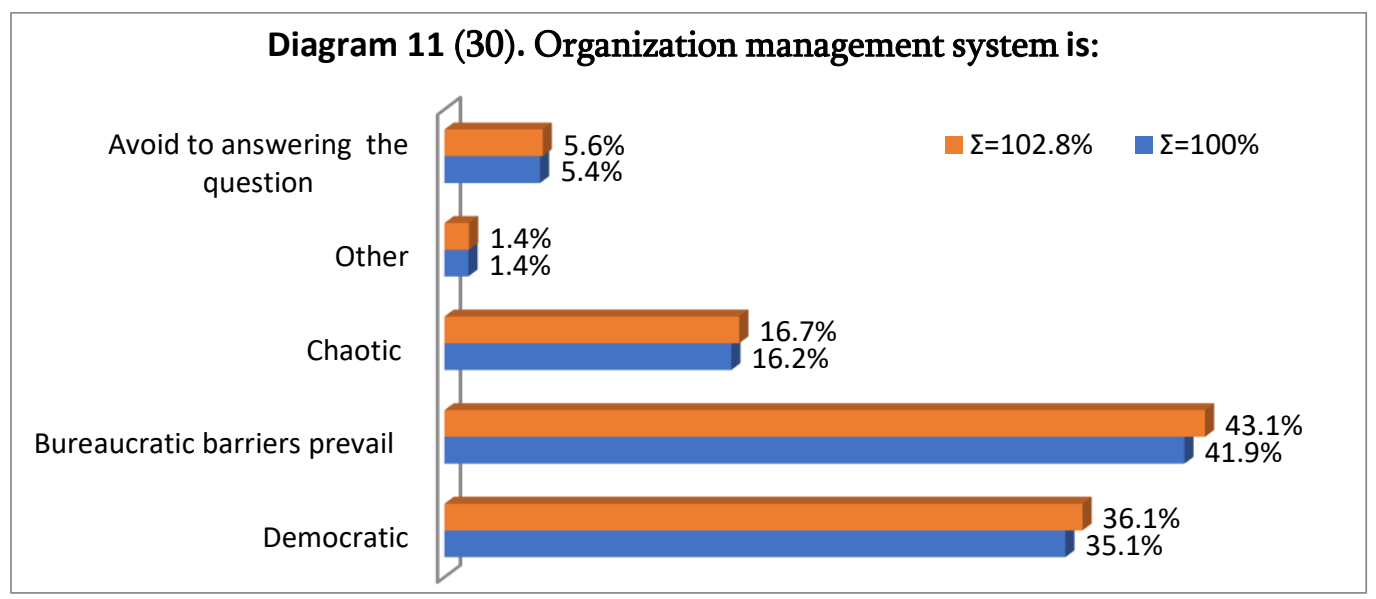

According to the students' survey results, $27 \%$ think that bureaucratic problems are severe in the administration, $38 \%$ think that it is noticeable, $30 \%$ think that it is less noticeable and $5 \%$ think that there is not such a problem in this direction. ${ }^{1}$ The

1 The Same; Diagram 18; pg. 126 
efficiency of the management system would be revealed by encouraging the supportive projects and activities of a knowledge triangle. However, on the example of the Faculty of Economics and Business, these links are very weak and spontaneous despite the great interest of business sector (Gulua, Ekaterine; Mikaberidze, Akaki, 2015). The knowledge-based management system, organizational culture allows for encouraging progressive, innovative ideas in any type of organization (Gulua, Ekaterine; Kharadze, Natalia, 2014), which becomes a fundamental basis for a real development, especially in the conditions of highly qualified personnel (Gulua, Ekaterine, 2013); (Gulua, Ekaterine;, 2014).

It is interesting to know how the academic personnel are reporting their positions. For $57 \%$ it is a board meeting, $46 \%$ select an informal environment, $4 \%$ - Social Network, $26.4 \%$ speak about the problems at all official meetings, almost $10 \%$ do not talk about problems. (See Diagram 12(33).

\section{Diagram 12(33). I talk about the existing problems:}

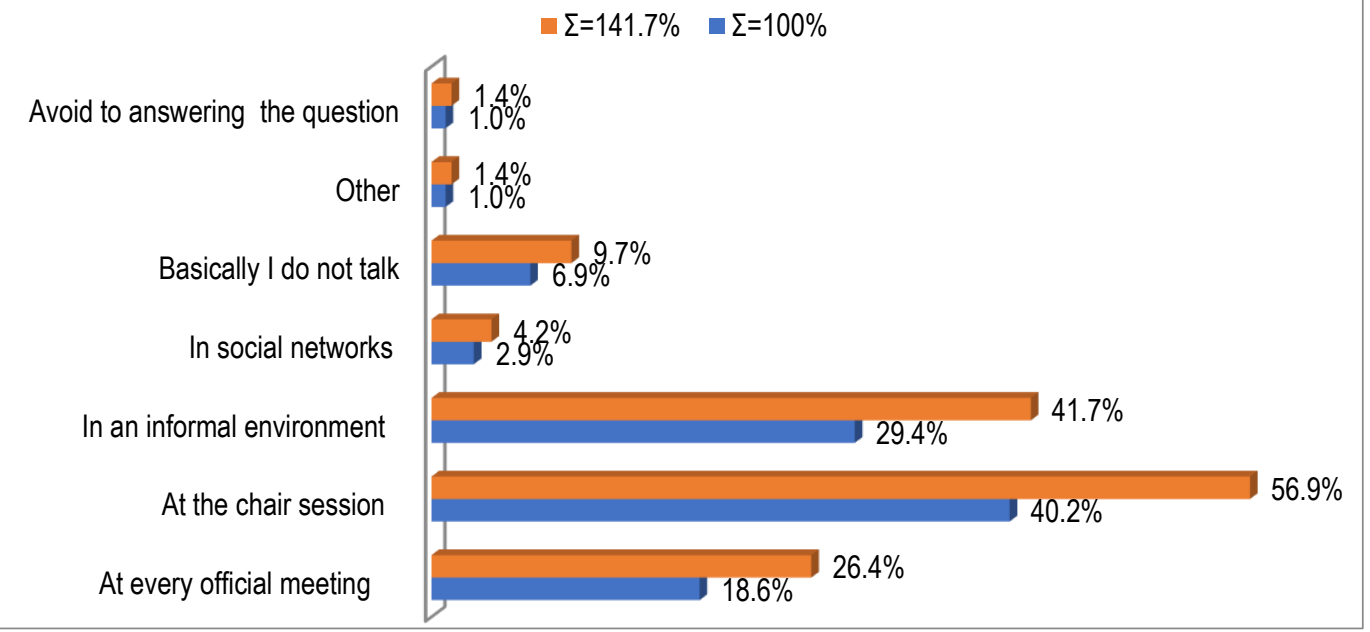

The indicator of the quality of democracy in the organization is the practice of expressing opinions also in an official form, in writing. Based on the research conducted under the auspices of the Human Potential Management Laboratory, the aim of which was to study the organizational culture at the university. 76 academic staff members were interviewed. The research analysis has shown the following: 19\% (14) of the academic personnel indicate that they "always" and "frequently" express their position in an official form, in writing, 36\% (27) sometimes use this form of expressing their position, 42\% (32) of the academic personnel indicate the answer "never", and 4\% (3) refrain from answering this question (Gulua, Ekaterine; Kharadze, Natalia;, 2018). The loyal attitude towards the employees' positions indicates to progressive and healthy processes in the organization. (76 units) $71 \%$ of the interviewed academic personnel in the research of organizational conflicts 
unambiguously expressed that showing their opinion causes an aggression in the organization and $24 \%$ answered "no", $94 \%$ of the administrative staff reported that their opinion often causes an aggression. Interestingly, the respondents of all categories (458 respondents were interviewed in total) confirmed this negative situation (Placeholder4).

An important representative body of the faculty is the board, 28\% (100 units) of fixed academic personnel are the members of the board according to the data of April 2018. $70 \%$ of our respondents did not turn out to be the members of the board and $16.4 \%$ reported that they are actively involved in discussions at the Faculty Council (See Diagram 13(34).

\section{Diagram 13 (34). At the Faculty Board:}

I only express my position by voting

I only express my position by voting

I rarely express my opinion

I am an active member

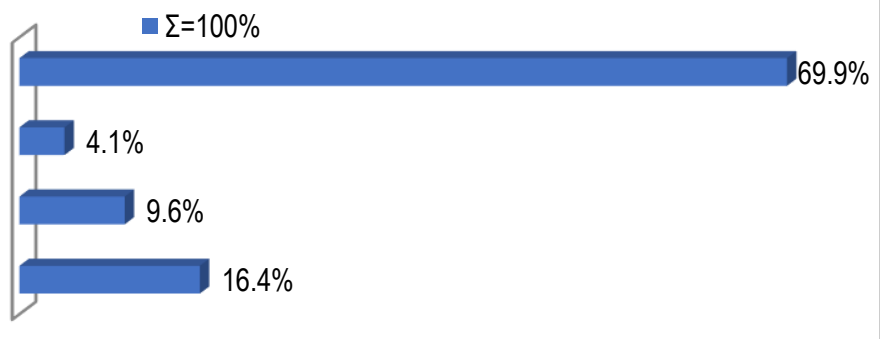

It was interesting to us how the respondents interviewed by us evaluate the board members. It was found out that $49 \%$ of the survey participants do not have information about the events in the board, $31 \%$ said that only a certain group is active in the board, $11 \%$ think that no one is active, $7 \%$ think that the activity of all members is high (See Diagram14 (35).

\section{Diagram14(35) At the Faculty Board:}

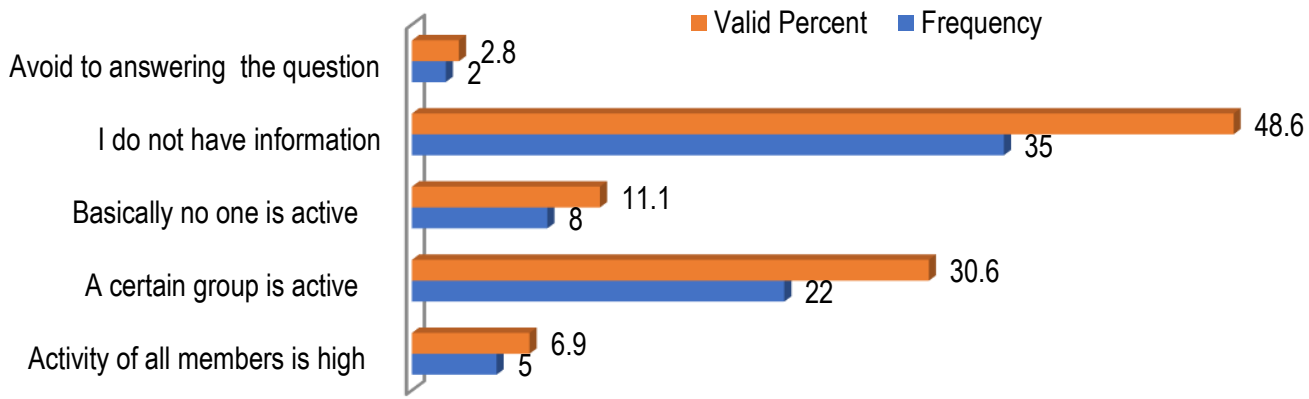

The fundamental basis of the organization functioning is the perception of justice from the members of the organization. $24 \%$ consider that the management system is fair, $51 \%$ consider the system to be dependent on individuals' good will, $7 \%$ have an 
extremely negative response to this question, $3 \%$ report that they do not know about it, $8 \%$ refrained from answering, and 7\% offered us their own variations (See Diagram 15(43).



It is the most important expression of justice, whether there are equal working conditions in the organization, or there is a discrimination? The extreme polarization of the answers was observed here - $47 \%$ think that the working conditions are equal, $50 \%$ think they are unequal and 3\% refrained from answering (See Diagram16(22).

\section{Diagram 16(22). Are all employees working on equal terms?}

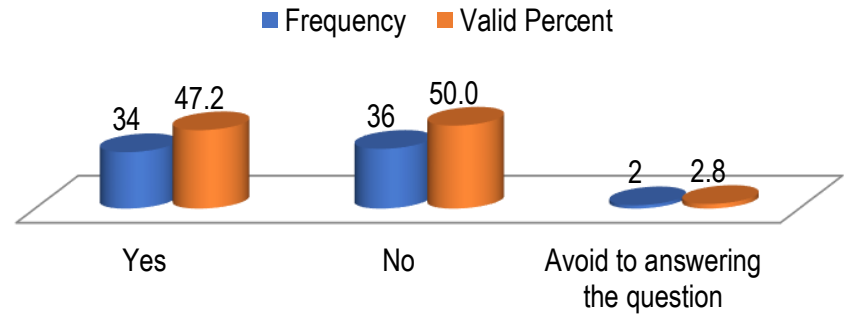

The students' survey showed that $92 \%$ of the respondents believe that lectures and seminars are not provided with equal technical conditions and $8 \%$ think that the conditions are equal. ${ }^{1}$

Based on the analysis of the abovementioned issues and scientific works (Kasradze, Tea, 2013) (Locke, William; Cummings, William K.; Fisher , Donald;, 2011); (Locke, William; Cummings, William K.; Fisher , Donald; 2011); (Kasradze, Tea, 2016);(Scott, Amy; Hershey, Metcalfe, 2006); (Kasradze, Tea; Zarnadze, Nino, 2018) ; (Kasradze, Tea, 2014) the following important issues ${ }^{2}$ were identified from the management challenges:

\footnotetext{
1 The same; Diagram 17, pg.125

2 https://www.tsu.ge/ge/about/budget/
} 
The main challenge in higher education management processes is the insecurity of democratic and fair principles. While this is the best form of management for the organizations, where the majority of their staff is highly qualified and has a high competence.

Non-transparent, unpredictable processes of management facilitate an insecure environment, maintain the culture of distrust; Prevent democracy and justice in the organization;

An important challenge is to develop and implement copyright protection mechanisms;

High and long-term stages of career development prevent attractiveness of the field for talents, highly qualified human resources;

The absence of working mechanisms for the career reserve system management of the academic staff hinders the attraction, preservation and stable growth of the best human resource;

The existing system of personnel selection does not provide transparency, trust, it promotes causing conflicts, blocking democratic processes in the organization. Thus, this system significantly hinders the fundamental principles of university success, such as ethics, academic freedom, impartiality and quality;

The formality in management processes is felt in the inability of the assessment system of lecturers by students. This process does not have a function of a managing mechanism, at the same time an evaluator's freedom, responsibility and competence are not shown;

In the existing conditions, representative elective bodies create an imitation of democracy, they cannot be creators of a real value.

\section{Ergonomic and infrastructural challenges of higher education}

It is impossible to give the proper quality of higher education services to the user - to the student without the ergonomic and infrastructural factors providing the process such as:

Well-equipped lecture and seminar halls for active teaching methods, rooms for academic personnel for individual work; a library, student groups' working space for working on team projects, proper size of auditoriums for introduction of active teaching methods, modern technical equipment, appropriate furniture, eating place, sports halls, incentives for students' informal relationships and students' relaxation environment;

Correctly regulated curriculum, an organized system of student services, correctly defined norms of loading for professors, administrative and technical personnel, electronic devices providing learning, scientific and management processes - the proper system of electronic proceedings, e-databases, proper devices of information 
storage. Proper tools of communication, flexible methods of timely delivery of information, means of providing internal and external formal or informal networks.

Proper lighting, heating, conditioning, noise regulating systems, sanitary-hygienic norms, proper lifts, safety management;

Although different universities are in a different position in this regard, however, development of technique and technologies gives more opportunity to support the education system. The first university of Georgia in terms of ergonomic and infrastructure condition can be said to be in a especially difficult state.

From the interviewed academic personnel 1 person positively evaluates the infrastructural situation, $59 \%$ think that it is satisfactory, $44 \%$ evaluate the situation as difficult, and 1 refrained from responding (See Diagram17(39).

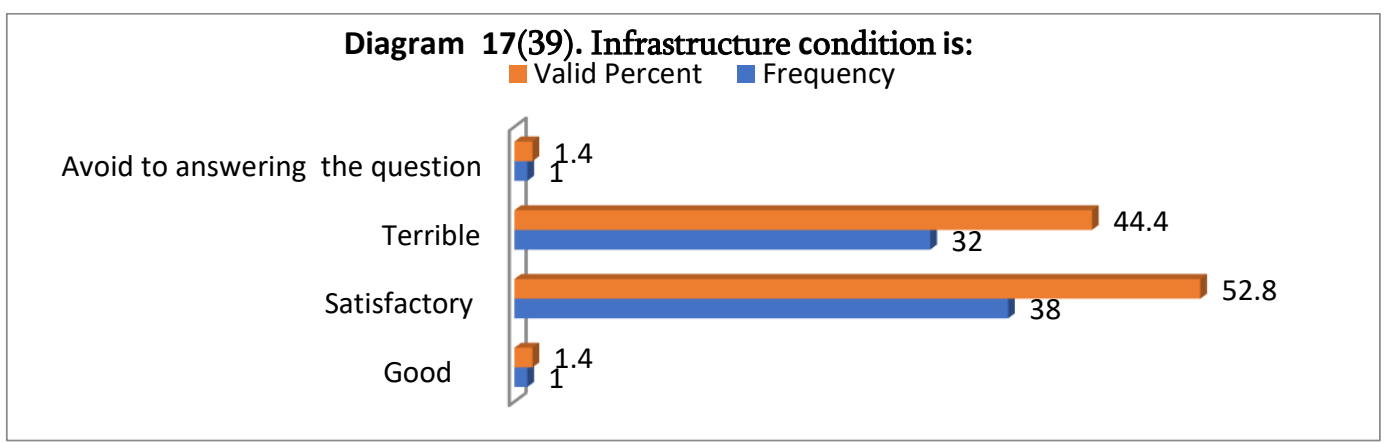

While assessing the condition of the TSU infrastructure, students are more categorical. $87 \%$ think that the situation is hard in this regard, $12 \%$ think it is average, $1 \%$ think it is very good 1 .

An important resource for educational institutions is textbooks, qualifications of the employed people and the quality of services provided depend on it. $56 \%$ of the interviewed lecturers buy the necessary textbooks themselves, $44 \%$ use the resources existing at the university (See Diagram 18(40).

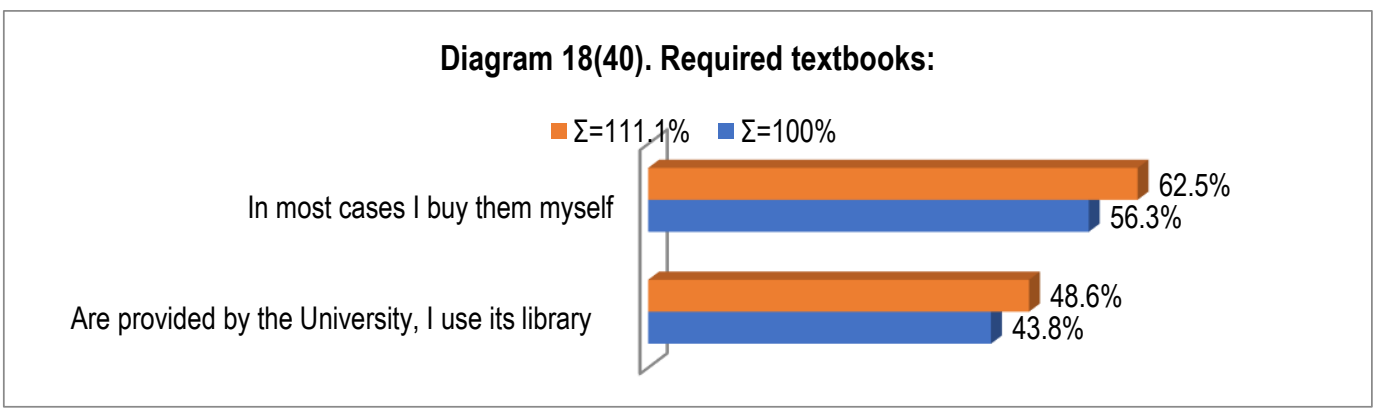

${ }^{1}$ The same; Diagram 24, pg.130. 
Pedagogical and scientific work is known to be related to noise because the person in parallel has to communicate with dozens of students, does teamwork with colleagues, has to attend sessions, board meetings. The necessity of constant suppression of the voices leads to a teacher's professional illness - it provokes diminished hearing. Therefore, students and lecturers' desks and chairs, the door of the room should not make a noise when moving. It is also important for the scientist after contact hours with students to have a cozy noise-free working environment for doing individual work, for evaluating students' papers, for scientific work which will help to restore energy, because this type of work is creative and needs a high level of concentration for thinking and attention.

$71 \%$ of the respondents reported that they have a cozy working environment in the university building, and 26\% think that they don't have such an environment, 3\% refrained from answering this question (See Diagram 19(47).

\section{Diagram 19(47). Do you have a cozy working environment at the university?}

- Frequency $\quad$ Valid Percent

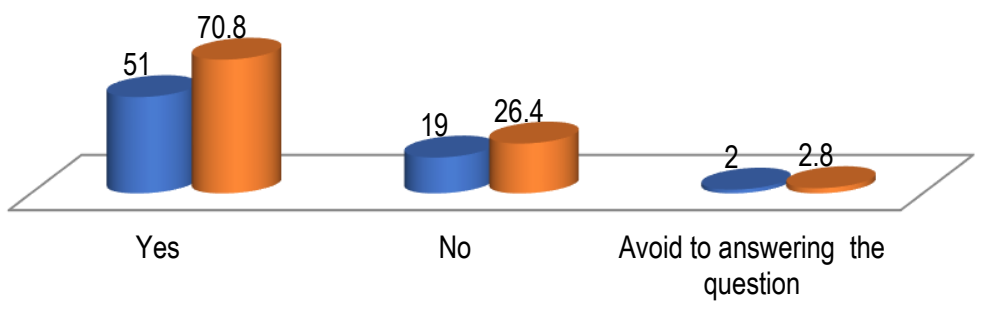

The qualitative analysis of the existing situation shows that only professors and in exceptional cases other categories of academic personnel who work in university scientific-research units or in administration are provided with an individual working room (Gulua, Ekaterine; 2011). Their number does not actually exceed 30\% while at the world's leading universities for scientific work, not only academic personnel, but also doctorate students are provided with an individual working place.

For evaluating the process of administering we also examined the condition of technical means. $24 \%$ never had any problems with the electronic bases, $40.3 \%$ rarely had $-36 \%$ of the respondents have responded to this question negatively (See Diagram 20(36). 


\section{Diagram20(36). Have you had problems with the el-bases?}

- Frequency $\quad$ Valid Percent

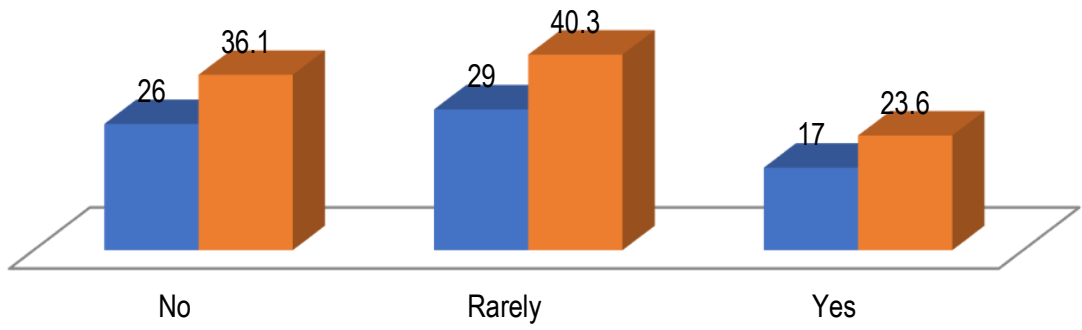

$26 \%$ of the interviewed students see the same problem severely, $36 \%$ often have problems with electronic bases, 30\% - rarely have, $8 \%$ did not have the similar problem 1 .

How much free the lecturers are when choosing work schedule and content - is an important question because the prestige of work and attitude towards an employee are determined by this criterion. is determined by and. It has turned out that $31 \%$ are in good condition in this respect and 69\% cannot choose a teaching discipline and work schedule (See Diagram 21(32).

\section{Diagram 21(32). Work schedule and lecture courses:}

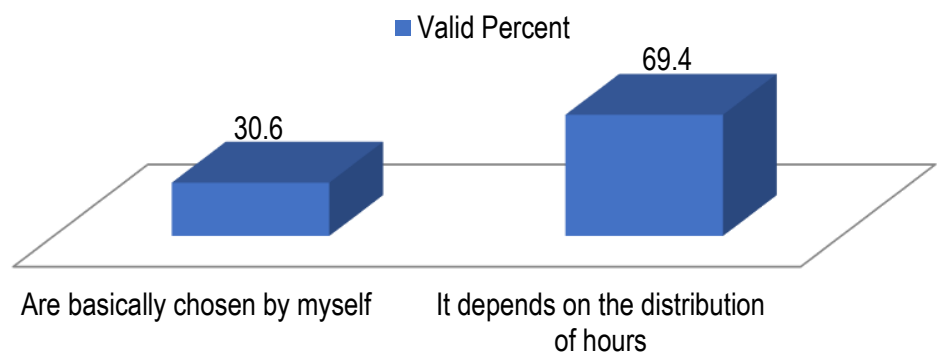

The time for students' studies is also not correctly planned, which has been demonstrated by the research conducted under the auspices of the Human Potential Management Laboratory. In particular, it has been revealed that the vast majority of students are employed, they finish work at 18 o'clock in the evening and the lectures in better case begin at 18 o'clock - the time required for transportation is nor taken into consideration, and in some universities learning begins in the morning hours or at 17 o'clock, it shows that such a schedule fundamentally objects to its implementing from the student's side, it makes a rule violation become a norm ("Prishtina"sh.a,

1 The same; Diagram 22, pg.129 
March 2013); (Kim \& Mauborgne, 2000); (Kharadze, Natalia; Gulua, Ekaterine, 2017); (Crawford I, M. Keen and S. Smith, 2009); (Kharadze, Natalia; Gulua, Ekaterine, 2017).

A lecturer's qualification is significantly defined by the depth of knowledge, which is directly related to specialization, it was found that $6 \%$ are specialized in $1-2$ subjects, $33 \%$ are specialized in 3-4 subjects, $20 \%$ - in 5-6 subjects, $42 \%$ had to study 7 and more subjects, it is too much to speak about the specialization of the latter, but it is not surprising, the change of the Soviet economics had a special impact on the specialty curricula of Economics and Business Faculty direction, respectively, studying disciplines also changed or radically changed their content. And working experience of a large part of the respondents, as I have mentioned earlier, is quite high (See Diagram 22(45).

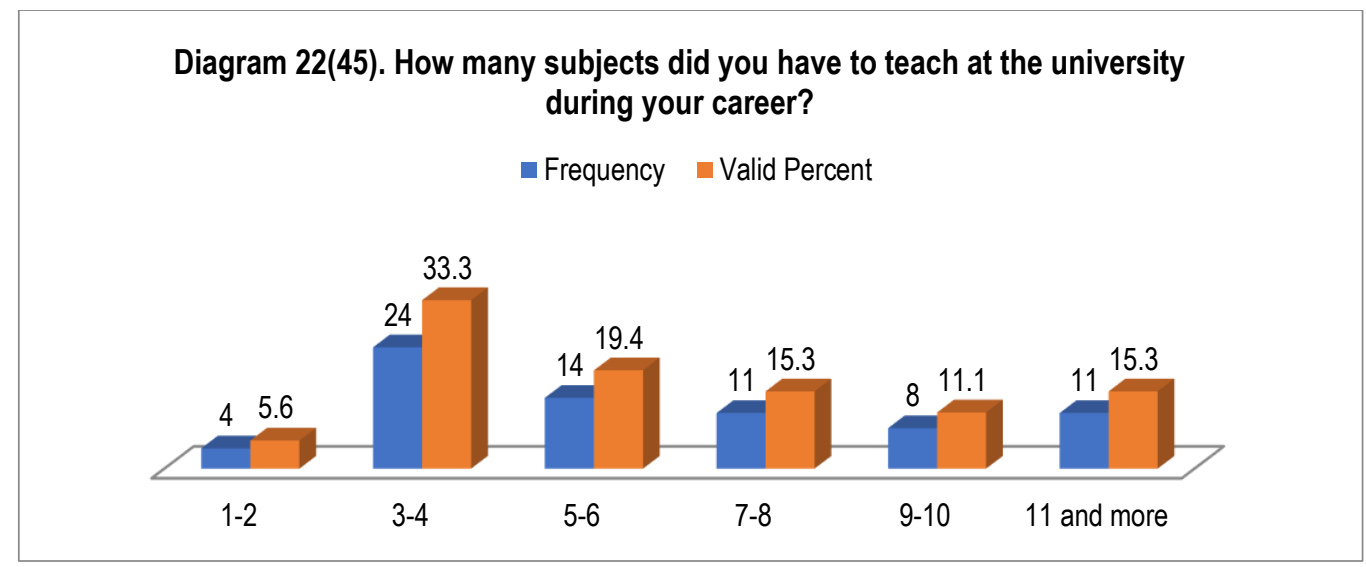

Along with the above-mentioned challenges, the reduction of the first choice of TSU as the preferred university by school-leavers also indicates the existence of important problems in the organization and the need for anti-crisis and contextual decision making. Consequently, priority directions should be defined that will help raising the university ranking (Gulua, Ekaterine, 2012).

Since the study involved the academic staff of the Faculty of Economics and Business, we were interested how they evaluated the university budget management, as they were able to state the competent opinion. It has turned out that $64 \%$ are not informed in this respect, which basically can be explained by their lack of interest in this issue, 8\% are satisfied and 26\% - dissatisfied(See Diagram 23(41). 


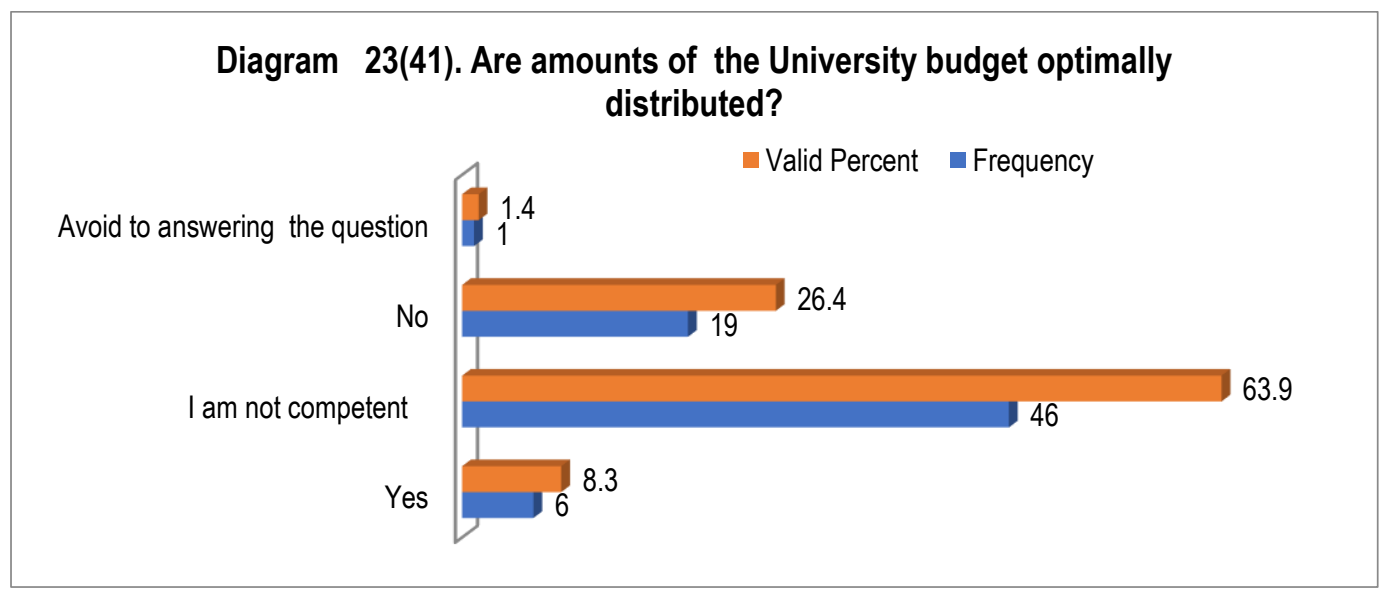

The amount of administrative staff in the whole amount of employees is interesting. In general, at TSU constantly employed is 5572, among them $47,7 \%$ is administrative and service personnel. The latest change in the law was positively reflected on this indicator, on the basis of which the assistants of a professor were transferred from administrative personnel into academic personnel. ${ }^{1}$ The perception of this fact by the respondents is as follows: $4 \%$ believe that the administrative personnel are insufficient; $18 \%$ believe that it is excessive; $38 \%$ report that it is sufficient, and 35\% think that it is not optimally distributed according to demand (See Diagram 24(29).

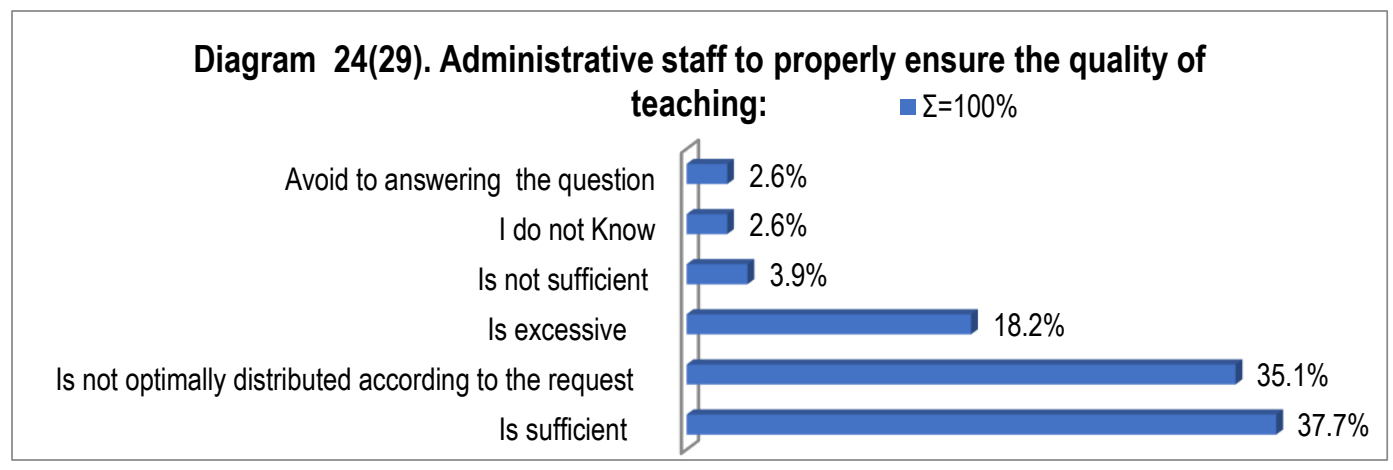

What is the attitude of academic personnel to the legislative acts regulating the field? $35 \%$ of the respondents think that the fundamental changes in this direction are necessary and 63\% think that the Law on Higher Education requires slight changes (See Diagram 25(44).

\footnotetext{
${ }^{1}$ Law of Georgia on Higher Education, Article 33, Paragraph 1.
} 


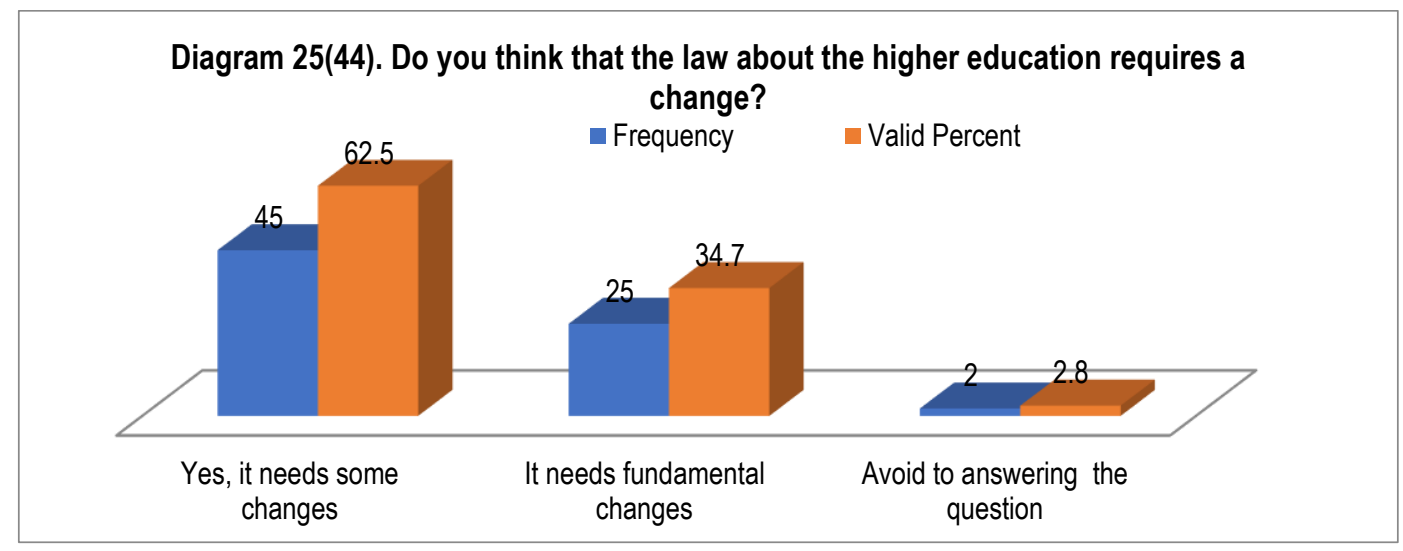

Based on the above-mentioned research and qualitative analysis, the following important issues have emerged from the challenges of Ergonomics and Infrastructure management:

The Environment is irrelevant to the content load of the higher education institution. The condition of the building makes it impossible to maintain sanitary-hygienic conditions;

The size of the most part of the auditoriums, the internal design and technical equipping level make it impossible to introduce active teaching methods, to lead a normal learning process;

Most part of the academic staff has no cozy, noise-free work space;

Unequal working conditions are an expression of discriminatory approach and exclude the feeling of equality;

There are no proper systematic mechanisms for sharing knowledge, information, cooperation and team work conditions, environmental technical capabilities;

The academic staff are limited in selecting and managing training schedules and subjects, which in every field shows that the job is non-prestigious. The similar organizing form of a job especially hinders combining the academic and scientific work, specializing in a particular scientific direction, concentrating;

Important attention should be paid to the workload norms of administrative and technical personnel, development, training, caring for promotion activities, and equipping them with proper technical means and knowledge.

We examined the preliminary prepared hypotheses with statistical methods. Namely, we used Pearson correlation analysis, the Chi-squared tests for confirming the reliability of the links between the variables and the linear regression, namely, the Anova test. 
Preliminary hypotheses have been verified by statistical methods. In particular, we used Pearson correlation analysis of pyroson, the Chi-squared tests to substantiate the reliability of the connections between the variables and linear regression, namely the ANOVA test.

H1: Variable Q16 (Is it acceptable for you to select personnel by competition?) affects the variables:

Q22 (Are all employees working on equal terms?);

Q23 (Cases of copyright violations);

Q44 (Do you think that the law about the higher education requires a change?).

H2: Variable - Q13 (Are the conditions and time frames for your career development officially clear?) affects the variables:

Q14 (Do you know who will replace you?);

Q22 (Are all employees working on equal terms?);

Q23 (Cases of copyright violations);

Q44 (Do you think that the law about the higher education requires a change?).

H3: Variable - Q14 (Do you know who will replace you?) affects the variables:

Q13 (Are the conditions and time frames for your career development officially clear?)

Q22 (Are all employees working on equal terms?);

Q23 (Cases of copyright violations);

Q44 (Do you think that the law about the higher education requires a change?).

H4: Variable - Q22 (Are all employees working on equal terms?) affects the variables:

Q16 (Is it acceptable for you to select personnel by competition?);

Q13 (Are the conditions and time frames for your career development officially clear?);

Q14 (Do you know who will replace you?);

Q23 (Cases of copyright violations);

Q44 (Do you think that the law about the higher education requires a change?).

H5: Variable - Q44 (Do you think that the law about the higher education requires a change?) affects the variables:

Q16 (Is it acceptable for you to select personnel by competition?);

Q14 (Do you know who will replace you?);

Q22 (Are all employees working on equal terms?);

H1 Hypothesis: To prove correlation between variables Q16, Q22, Q23 and Q44 we have made Pearson Correlation Analysis Test. By the test weak connection has been confirmed (In the range between $-0,5$ and 0.5 ). 
Table 1. Pearson Correlation Analysis (Q16, Q22, Q23, Q44)

\begin{tabular}{|l|l|l|l|l|l|}
\hline \multicolumn{2}{|l|}{ Correlations } & $\mathrm{Q} 16$ & $\mathrm{Q} 22$ & $\mathrm{Q} 23$ & $\mathrm{Q} 44$ \\
\hline \multirow{4}{*}{$\mathrm{Q} 16$} & Pearson Correlation & 1 & $.349^{* *}$ & $.347^{* *}$ & $.307^{* *}$ \\
\cline { 2 - 6 } & Sig. (2-tailed) & & .003 & .003 & .009 \\
\cline { 2 - 6 } & $\mathrm{N}$ & 72 & 72 & 72 & 72 \\
\hline
\end{tabular}

The Chi-squared tests have shown that the connection between these variables: Q16 and Q22, Q16 and Q44 are reliable. In both cases the sigma is less than 0,005 (See Table 2 and Table3).

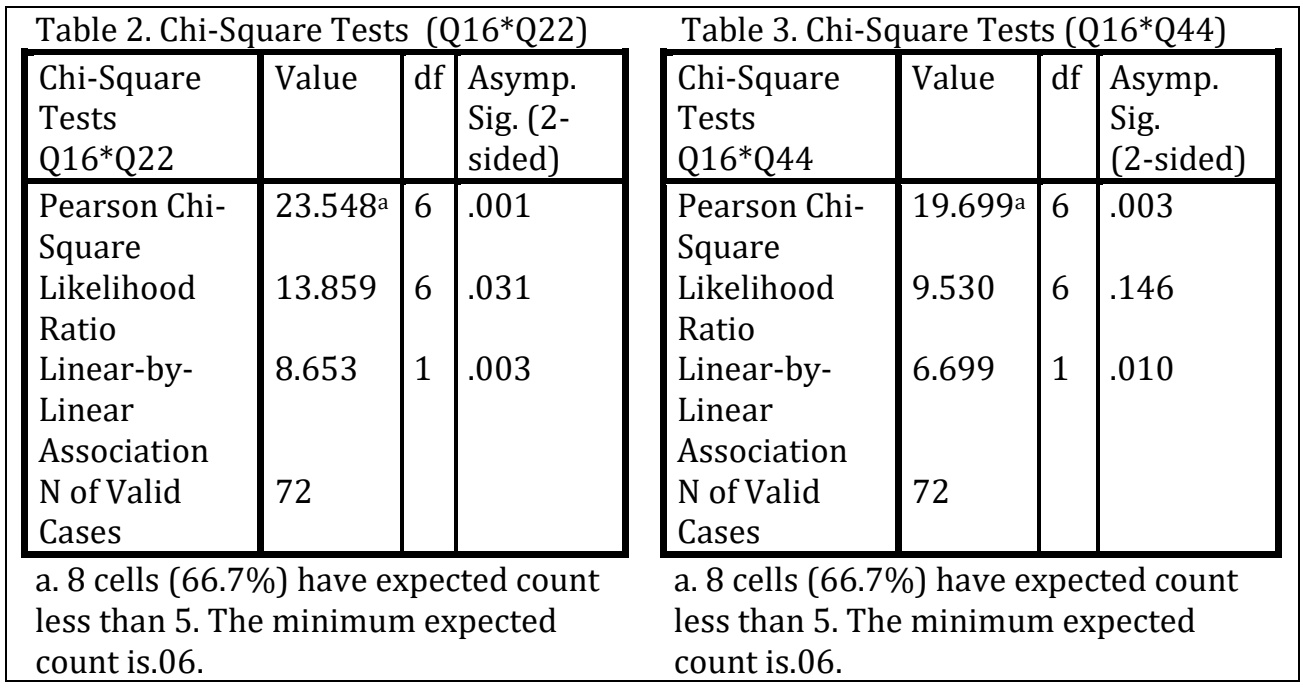

By the linear regression analysis, the ANOVA test has shown that the model $(\mathrm{Q} 16, \mathrm{Q} 22$, Q23, Q44) is reliable, because the sigma is less than 0,005 (See Table 4) Between Q22, Q23, and Q44 the more important is Q44.

Table 4. Linear regression (ANOVAa)

\begin{tabular}{|c|c|c|c|c|c|}
\hline Model & Sum of Squares & $\mathrm{df}$ & Mean Square & $F$ & Sig. \\
\hline $\begin{array}{l}\text { Regressio } \\
\mathrm{n} \\
\text { Residual } \\
\text { Total }\end{array}$ & $\begin{array}{l}7218.959 \\
24975.041 \\
32194.000\end{array}$ & $\begin{array}{l}3 \\
68 \\
71\end{array}$ & $\begin{array}{l}2406.320 \\
367.280\end{array}$ & 6.552 & $.001^{\mathrm{b}}$ \\
\hline
\end{tabular}

a. Dependent Variable: 16

b. Predictors: (Constant), 44, 23, 22

H2 Hypothesis. By Pearson Correlation Analysis Test the correlation between Q13 and Q14, Q22, Q23, Q35 variables has been confirmed. The links between them are week (In the range between -0.5 and 0.5) (See Table 5).

Table 5. Pearson Correlation Analysis (Q13, Q14, Q22, Q23, Q35)

\begin{tabular}{|l|l|l|l|l|l|}
\hline Correlations & Q13 & Q14 & Q22 & Q23 & Q35 \\
\hline
\end{tabular}




\begin{tabular}{|l|l|l|l|l|l|l|}
\hline \multirow{2}{*}{ Q13 } & $\begin{array}{l}\text { Pearson } \\
\text { Correlation }\end{array}$ & 1 & $.487^{* *}$ & $.328^{* *}$ & $.345^{* *}$ & $.336^{* *}$ \\
\cline { 2 - 7 } & Sig. (2-tailed) & & .000 & .005 & .003 & .004 \\
\cline { 2 - 7 } & $\mathrm{N}$ & 72 & 72 & 72 & 72 & 72 \\
\hline
\end{tabular}

**. Correlation is significant at the 0.01 level (2-tailed).

The Chi-squared tests have shown that the connection between the variables: Q13 and Q23 is reliable. In this case the sigma is less than 0,005 (See Table 6).

Table 6. Chi-Square Tests (Q13*Q23)

\begin{tabular}{|l|l|l|l|}
\hline Chi-Square Tests Q13*Q23 & Value & df & Asymp. Sig. (2-sided) \\
\hline Pearson Chi-Square & $44.545^{\mathrm{a}}$ & 20 & .001 \\
Likelihood Ratio & 43.410 & 20 & .002 \\
Linear-by-Linear Association & 8.443 & 1 & .004 \\
N of Valid Cases & 72 & & \\
\hline
\end{tabular}

a. 24 cells $(80.0 \%)$ have expected count less than 5 . The minimum expected count is.03.

By the linear regression analysis, the ANOVA test has shown that the model $(\mathrm{Q} 13, \mathrm{Q} 14$, Q22, Q23, Q35) is reliable, because the sigma is less than 0,005. Between Q14, Q22, Q23 and Q35) the more important is Q35 (See Table 7).

Table 7. Linear regression (ANOVAa)

\begin{tabular}{|ll|l|l|l|l|l|}
\hline Model & & Sum of Squares & $\mathrm{df}$ & Mean Square & F & Sig. \\
\hline \multirow{4}{*}{1} & Regressio & 13929.073 & 4 & 3482.268 & 11.863 & $.000^{\mathrm{b}}$ \\
& $\mathrm{n}$ & & & & & \\
& Residual & 19666.580 & 67 & 293.531 & & \\
& Total & 33595.653 & 71 & & & \\
\hline
\end{tabular}

a. Dependent Variable: Q13,

b. Predictors: (Constant), Q35 Q23 Q14, Q22,

H3 Hypothesis. The existence of correlation between Q14, Q13, Q22, Q23, Q44 variables has been confirmed by the Pearson Correlation Analysis Test. However, the connections between Q14 and Q13, Q23, Q44 are week (In the range between -0,5 and 0.5); The link between Q14 and Q22 is medium (In the range between $-0,7$ and 0.7 ) (Table 8).

Table 8. Pearson Correlation Analysis (Q14, Q13, Q22, Q23, Q44)

\begin{tabular}{|l|l|l|l|l|l|l|}
\hline \multicolumn{2}{|l|}{ Correlations } & Q14 & Q13 & Q22 & Q23 & Q44 \\
\hline \multirow{4}{*}{ Q14 } & Pearson Correlation & 1 & $.487^{* *}$ & $.693^{* *}$ & $.319^{* *}$ & $.328^{* *}$ \\
\cline { 2 - 7 } & Sig. (2-tailed) & & .000 & .000 & .006 & .005 \\
\cline { 2 - 7 } & $\mathrm{N}$ & 72 & 72 & 72 & 72 & 72 \\
\hline
\end{tabular}

The Chi-squared test has shown that the connections between the variables: Q14 and Q22 is reliable. The sigma in this case is less than 0,005 (see Table 9). 
Table 9. Chi-Square Tests (Q14*Q22)

\begin{tabular}{|l|l|l|l|}
\hline Chi-Square Tests Q14*Q22 & Value & df & Asymp. Sig. (2-sided) \\
\hline Pearson Chi-Square & $39.579^{\mathrm{a}}$ & 6 & .000 \\
Likelihood Ratio & 19.430 & 6 & .003 \\
Linear-by-Linear Association & 34.063 & 1 & .000 \\
N of Valid Cases & 72 & & \\
\hline
\end{tabular}

By the linear regression analysis, the ANOVA test has shown that the model $(\mathrm{Q} 14, \mathrm{Q} 13$, Q22, Q23, Q44) is reliable, because the sigma is less than 0,005. Between Q13, Q22, Q23 and Q44) the more important is Q44. (See Table 10).

Table 10. Linear regression (ANOVA $)$

\begin{tabular}{|ll|l|l|l|l|l|}
\hline \multicolumn{2}{|l|}{ Model } & $\begin{array}{l}\text { Sum of } \\
\text { Squares }\end{array}$ & df & Mean Square & F & Sig. \\
\hline \multirow{4}{*}{1} & Regression & 19997.341 & 4 & 4999.335 & 21.476 & $.000^{\mathrm{b}}$ \\
\cline { 3 - 5 } & Residual & 15596.979 & 67 & 232.791 & & \\
& Total & 35594.319 & 71 & & & \\
\hline
\end{tabular}

a. Dependent Variable: Q14

b. Predictors: (Constant), Q44, Q13, Q23, Q22

H4 Hypothesis. To prove H4 hypothesis we have made Pearson Correlation Analysis Test. By the test the correlation between variables Q22 and Q16, Q13, Q23, Q44 has been confirmed. The link between Q22 and Q16, Q33, Q44 is week. The links between Q1 and Q19 are week (In the range between -0,5 and 0.5). The link between Q22 and Q44 is medium (In the range between -0.7 and 0.7) (See Table 11).

Table 11. Pearson Correlation Analysis (Q22, Q16, Q13, Q23, Q44)

\begin{tabular}{|l|l|l|l|l|l|l|l|}
\hline \multicolumn{2}{|c|}{} & $\mathrm{Q} 22$ & $\mathrm{Q} 16$ & $\mathrm{Q} 13$ & $\mathrm{Q} 14$ & $\mathrm{Q} 23$ & $\mathrm{Q} 44$ \\
\hline \multirow{4}{*}{ Q22 } & $\begin{array}{l}\text { Pearson } \\
\text { Correlation }\end{array}$ & 1 & $.349^{* *}$ & $.328^{* *}$ & $.693^{* *}$ & $.473^{* *}$ & $.491^{* *}$ \\
\cline { 2 - 8 } & Sig. (2-tailed) & & .003 & .005 & .000 & .000 & .000 \\
\cline { 2 - 8 } & $\mathrm{N}$ & 72 & 72 & 72 & 72 & 72 & 72 \\
\hline
\end{tabular}

**. Correlation is significant at the 0.01 level (2-tailed).

The Chi-squared test has shown that the connections between the variables: Q22 and Q16, Q14, Q23 Q44 is reliable. The sigma is less than 0,005 (See Tables: 12, 13, 14, 15).

Table 12. Chi-Square Tests $(22 * 16)$

\begin{tabular}{|l|l|l|l|}
\hline $\begin{array}{l}\text { Chi-Square } \\
\text { Tests } 22^{*} 16\end{array}$ & Value & df & $\begin{array}{l}\text { Asymp. } \\
\text { Sig. (2- } \\
\text { sided) }\end{array}$ \\
\hline $\begin{array}{l}\text { Pearson Chi- } \\
\text { Square }\end{array}$ & $\begin{array}{l}23.54 \\
8^{\mathrm{a}}\end{array}$ & 6 & .001 \\
$\begin{array}{l}13.85 \\
\text { Ratio }\end{array}$ & 6 & .031 \\
\hline
\end{tabular}

Table 13. Chi-Square Tests $(22 * 14)$

\begin{tabular}{|l|l|l|l|}
\hline $\begin{array}{l}\text { Chi-Square } \\
\text { Tests } 22^{*} 14\end{array}$ & Value & df & $\begin{array}{l}\text { Asymp. } \\
\text { Sig. (2- } \\
\text { sided) }\end{array}$ \\
\hline $\begin{array}{l}\text { Pearson Chi- } \\
\text { Square } \\
\text { Likelihood Ratio }\end{array}$ & 39.579 a & 6 & .000 \\
\hline
\end{tabular}




\begin{tabular}{|l|l|l|l|} 
Linear-by- & 8.653 & 1 & .003 \\
Linear & & & \\
Association & & & \\
N of Valid Cases & 72 & & \\
\hline
\end{tabular}

a. 8 cells $(66.7 \%)$ have expected count less than 5 . The minimum expected count is.06.

Table 14. Chi-Square Tests $(22 * 23)$

\begin{tabular}{|c|c|c|c|}
\hline $\begin{array}{l}\text { Chi-Square } \\
\text { Tests } 22 * 23\end{array}$ & Value & $\mathrm{df}$ & $\begin{array}{l}\text { Asymp. } \\
\text { Sig. (2- } \\
\text { sided) }\end{array}$ \\
\hline $\begin{array}{l}\text { Pearson Chi- } \\
\text { Square } \\
\text { Likelihood } \\
\text { Ratio } \\
\text { Linear-by- } \\
\text { Linear } \\
\text { Association } \\
\text { N of Valid Cases }\end{array}$ & $\begin{array}{l}32.86 \\
9^{a} \\
23.99 \\
3 \\
15.90 \\
6 \\
72 \\
\end{array}$ & $\begin{array}{l}8 \\
8 \\
1\end{array}$ & $\begin{array}{l}.000 \\
.002 \\
.000\end{array}$ \\
\hline
\end{tabular}

a. 9 cells $(60.0 \%)$ have expected count

less than 5 . The minimum expected count is.06.

\begin{tabular}{|l|l|l|l|}
$\begin{array}{l}\text { Linear-by- } \\
\text { Linear }\end{array}$ & 34.063 & 1 & .000 \\
$\begin{array}{l}\text { Association } \\
\text { N of Valid Cases }\end{array}$ & 72 & & \\
\hline
\end{tabular}

a. 9 cells $(75.0 \%)$ have expected count less than 5 . The minimum expected count is.11.

Table 15. Chi-Square Tests $(22 * 23)$

\begin{tabular}{|c|c|c|c|}
\hline $\begin{array}{l}\text { Chi-Square } \\
\text { Tests } 22 * 44\end{array}$ & Value & $\mathrm{df}$ & $\begin{array}{l}\text { Asymp. Sig. } \\
\text { (2-sided) }\end{array}$ \\
\hline Pearson Chi- & 20.49 & 4 & .000 \\
\hline Square & & & \\
\hline Likelihood Ratio & 10.51 & 4 & .033 \\
\hline Linear-by- & 17.14 & 1 & .000 \\
\hline Linear & 5 & & \\
\hline Association & & & \\
\hline $\mathrm{N}$ of Valid Cases & 72 & & \\
\hline
\end{tabular}

By the linear regression analysis, the ANOVA test has shown that the model (Q22, Q16, $\mathrm{Q} 13, \mathrm{Q} 14, \mathrm{Q} 23, \mathrm{Q} 44)$ is reliable, because the sigma is less than 0,005 Between Q16, Q13, Q14, Q23, Q44 the more important is Q44. (see Table 16).

Table 16. Linear regression (ANOVA $\left.{ }^{a}\right)$

\begin{tabular}{|ll|l|l|l|l|l|}
\hline Model & & Sum of Squares & df & Mean Square & F & Sig. \\
\hline \multirow{4}{*}{1} & Regression & 12179.694 & 5 & 2435.939 & 25.452 & $.000^{\text {b }}$ \\
& Residual & 6316.751 & 66 & 95.708 & & \\
& Total & 18496.444 & 71 & & & \\
\hline
\end{tabular}

a. Dependent Variable: Q22

b. Predictors: (Constant), Q44, Q13, Q23, Q16, Q14

H5 Hypothesis. The existence of correlation between variables Q44 and Q16, Q14, Q22 has been confirmed by the Pearson Correlation Analysis Test. However, the connections between them are week (In the range between -0,5 and 0.5); (Table 17).

Table 17. Pearson Correlation Analysis (Q44, Q16, Q14, Q22)

\begin{tabular}{|l|l|l|l|l|l|}
\hline \multicolumn{2}{|l|}{ Correlations } & Q44 & Q16 & Q14 & Q22 \\
\hline \multirow{2}{*}{$\begin{array}{l}\text { Q4 } \\
4\end{array}$} & Pearson Correlation & 1 & $.307^{* *}$ & $.328^{* *}$ & $.491^{* *}$ \\
\cline { 2 - 6 } & & & & & \\
\cline { 2 - 6 } & Sig. (2-tailed) & & .009 & .005 & .000 \\
\hline
\end{tabular}

**. Correlation is significant at the 0.01 level (2-tailed).

The Chi-squared test has shown that the connections between the variables: Q44 and Q16, Q22 is reliable. The sigma is less than 0,005 (see Tables: 18, 19). 
Table 18. Chi-Square Tests $(44 * 16)$

\begin{tabular}{|l|l|l|l|}
\hline $\begin{array}{l}\text { Chi-Square } \\
\text { Tests } 44^{*} 16\end{array}$ & Value & df & $\begin{array}{l}\text { Asymp. } \\
\text { Sig. (2- } \\
\text { sided) }\end{array}$ \\
\hline $\begin{array}{l}\text { Pearson Chi- } \\
\text { Square } \\
\text { Likelihood } \\
\text { Ratio } \\
\text { Linear-by- } \\
\text { Linear } \\
\text { Association } \\
\text { N of Valid } \\
\text { Cases }\end{array}$ & 10.510 & 4 & .033 \\
\hline
\end{tabular}

a. 5 cells $(55.6 \%)$ have expected count less than 5 . The minimum expected count is.06.
Table 19. Chi-Square Tests $(44 * 22)$

\begin{tabular}{|l|l|l|l|}
\hline $\begin{array}{l}\text { Chi-Square } \\
\text { Tests } 44^{*} 22\end{array}$ & Value & df & $\begin{array}{l}\text { Asymp. } \\
\text { Sig. (2- } \\
\text { sided) }\end{array}$ \\
\hline $\begin{array}{l}\text { Pearson Chi- } \\
\text { Square } \\
\text { Likelihood } \\
\text { Ratio } \\
\text { Linear-by- } \\
\text { Linear } \\
\text { Association } \\
\text { N of Valid } \\
\text { Cases }\end{array}$ & $17.491^{\mathrm{a}}$ & 4 & .000 \\
\hline
\end{tabular}

a. 5 cells (55.6\%) have expected count less than 5 . The minimum expected count is. 06 .

By the linear regression analysis, the ANOVA test has shown that the model (Q44, $\mathrm{Q} 16, \mathrm{Q} 14, \mathrm{Q} 22)$ is reliable, because the sigma is less than 0,005 Between Q16, Q14, Q22the more important is Q22. (see Table 20).

Table 20. Linear regression (ANOVA $\left.{ }^{\mathrm{a}}\right)(\mathrm{Q} 44, \mathrm{Q16}, \mathrm{Q14}, \mathrm{Q} 22)$ ANOVA $^{\mathrm{a}}$

\begin{tabular}{|ll|l|l|l|l|l|}
\hline \multicolumn{1}{|c|}{ Model } & & Sum of Squares & $\mathrm{df}$ & Mean Square & $\mathrm{F}$ & Sig. \\
\hline \multirow{4}{*}{1} & Regression & 4772.882 & 3 & 1590.961 & 8.071 & $.000^{\mathrm{b}}$ \\
& Residual & 13403.993 & 68 & 197.118 & & \\
& Total & 18176.875 & 71 & & & \\
\hline
\end{tabular}

a. Dependent Variable: Q44

b. Predictors: (Constant), Q22, Q16, Q14

Thus, the listed hypotheses have been proved.

\section{Bibliography}

[1] Al-Hawaj, Abdulla Y. ; Elali, Wajeeh;. (2008). Higher Education in the TwentyFirst Century: Issues and Challenges. London: Taylor \& Francis Group.

[2] Antia, Vakhtang; (2018, December). Economy - oriented Education and the Management Priorities of the State Higher Education Institutions. Economics, pp. 6-17.

[3] Babo, Rosalina; Azevedo, Ana;. (2012). Higher education institutions and learning management systems: adoption and standardization. Hershey: IGI Global.

[4] Gulua, Ekaterine. (2012). "The Post-Crisis Contextual Decisions in Business Organisations. Proceedings of the International Scientific-Practical Conference: "Globalization, Contemporary Problems of International Business and Development Trends" (pp. 245-250). Tbilisi: Universal.

[5] Gulua, Ekaterine. (2017 April-June). Modern Challenges of Higher Education. Economics and Business, Business and Economics Refereed and Reviewed 
International Scientific and Practical Journal of the Faculty of Economics and Business, Ivane Javakhishvili Tbilisi State University, Volume X, N2, pp. 112132.

[6] Gulua, Ekaterine. (2013, March-April). Talent-Management - Actual Direction of Human Potential Management. "Economics and Business"- International Refereed and Reviewed Scientific and Practical Journal of the Faculty of Economics and Business, Ivane Javakhishvili Tbilisi State University, N2,, pp. 85-98.

[7] Gulua, Ekaterine;. (2018, Jul 24). Challanges of Higher Education Learning and Scientific Research Process Management. European Journal of Multtidisciplinary Studies, Volume 3. Issue 3, pp. 80-100.

[8] Gulua, Ekaterine;. (2014). Globalization and Human Resource Management Challenges. Proceedings of IV International Conference: Globalization and Statistics, Ivane Javakhishvili Tbilisi State University (p. 153). Tbilisi: Universal.

[9] Gulua, Ekaterine; Kharadze, Natalia. (2014). Knowledge-Based Organizational Culture Development Challenges in Small and Medium Sized Enterprises of Post-Soviet Georgia. 3rd International Symposium: "Advances in Busines Management Towards Systemic Approach" (pp. 93-96). Perugia: Business Systems Laboratory.

[10] Gulua, Ekaterine; Kharadze, Natalia;. (2018, Jul 24). Employed Students' Development Challenges in Georgia. European Journal of Interdisciplinary Studies, Volume4, Issue 2, pp. 188-208.

[11] Gulua, Ekaterine; Kharadze, Natalia;. (2017, Octomber 6). Impact of Time Management on Personal Development of Master's Degree Students. European Journal of Social Sciences Education and Research, pp. 110-118.

[12] Gulua, Ekaterine; Kharadze, Natalia;. (2018, March 2). Organization Culture Management Challenges. European Journal of Interdisciplinary Studies, pp. 67-79.

[13] Gulua, Ekaterine; Mikaberidze, Akaki. (2015). Exigency of Effective Cooperation between Higher Education Institutions and Business Organizations in Post Soviet Georgia. Proceedings of Multidisciplinary Academic Conference on Economics, Management and Marketing (pp. 7-11). Prague: EBSCO INFORMATION SERVICES.

[14] Gulua, Ekaterine;. (2017). Strategic Human Resource Management (Lecture Course). Tbilisi.

[15] Gulua, Ekaterine;. (2011). The Ethical Management Issues in Organisation. Proceedings of the Scientific-Practical Conference Devoted to the 20th Anniversary of Kutaisi University: "Contemporary Problems of Economics and Business and Trends of Development", (pp. 54-57). Kutaisi.

[16] Hussey, Trevor ; Smith, Patrick ;. (2010). The Trouble with Higher Education, A Critical Examination of our Universities. London, New York: Taylor \& Francis. 
[17] Kasradze, Tea. (2014). Investment Environment in Georgia and and Domestic Investment Potential of the Country. International Scientific-Analytical Journal Ekonomisti \#5, pp. 33-43.

[18] Kasradze, Tea. (2013). Poverty - A Global Socio-Economic Problem. Caucasus International University HERALD \#5, pp. 15-18.

[19] Kasradze, Tea. (2016). Public Finance Management Reform in Georgia and Its Compatibility with the EU practice. The works of the International Scientific Conference: European Union Association Agreement:legal, political and economic aspects. Tbilisi: Caucasus International University.

[20] Kasradze, Tea. (2018). Trends of Financing for Development in Georgia. American Scientific Journal \#21, pp. 32-40.

[21] Kasradze, Tea; Zarnadze, Nino. (2018, May). Enhancing Workforce Competitiveness through Improving Quality of Education - An Indispensable Means for Overcoming Poverty. International Journal of Innovative Technologies in Economy, pp. 19-21.

[22] Kharadze, Natalia; Gulua, Ekaterine. (2016). Self Management Peculiarities of Master's Students in Georgia. CHALLENGES OF GLOBALIZATION IN ECONOMICS AND BUSINESS (33. 613-616). Tbilisi: Universal.

[23] Kharadze, Natalia; Gulua, Ekaterine. (2017). Time Management Pecularities of Shota Rustaveli State University MA Students. Innovative Economics and Management, 20-25.

[24] Kharadze, Natalia; Gulua, Ekaterine. (2017). Time Management Peculiarities Based on Gender. I International Scientific and Practical Conference: Forsightmanagement: best world practice of development and integration of education, science and business (pp. 39-42). Kyiv-Tbilisi: Vyshemyrkyi.

[25] Kharadze, Natalia; Gulua, Ekaterine;. (2018). Analyze of Students' Attitude Survey of Professor Evaluation Criteria. Journal Innovative Economics and Management, Volume 5, pp. 122-131.

[26] Kharadze, Natalia; Gulua, Ekaterine; Duglaze, Davit. (2017, Octomber 6). FreeTime Management among Master's Degree Students of Georgia. European Journal of Social Sciences Education and Research, pp. 24-33.

[27] Kharadze, Natalia; Gulua, Ekaterine;. (2018). Implications of Students' Attitude Survey of Professor Evaluation Criteria. Journal Innovative Economics and Management, Valume 5, pp. 122-131.

[28] Kharadze, Natalia; Gulua, Ekaterine;. (2018, March 2). Organization Conflict Management Challenges. European Journal of Economics and Business Studies, pp. 30-41.

[29] Kharadze, Natalia; Gulua, Ekaterine;. (2018, jul 24). Personal Development Peculiarities on Gender Perspective in Georgia. European Journal of Multidisciplinary Studies, pp. 111-123.

[30] Locke, William; Cummings, William K.; Fisher, Donald;. (2011). Changing Governance and Management in Higher Education. London New York: Springer Science+Business Media B.V. 
[31] Meek, L. V., Goedegebuure, L., Santiago, R., \& Carvalho, T. (2010). The Changing Dynamics of Higher Education Middle Management. London New York: Springer Science+Business Media B.V.

[32] Schwab, Klaus; Sala-i-Martín, Xavier; Samans, Richard;. (2017-2018). The Global Competitiveness Report 2017-2018. World Economic Forum,.

[33] Scott, Amy; Hershey, Metcalfe. (2006). Knowledge management and higher education: a critical analysis. London, Singapore, Melbourne: Idea Group Inc.

[34] Law of Georgia on Higher Education, Article 33, Paragraph 1. 